Egyptian Journal of Aquatic Biology \& Fisheries

Zoology Department, Faculty of Science,

Ain Shams University, Cairo, Egypt.

ISSN $1110-6131$

Vol. 23(3): $69-81$ (2019)

www.ejabf.journals.ekb.eg

\title{
Age, growth and population structure of bogue, Boops boops, in the mediterranean waters front Alexandria, Egypt
}

\author{
Ahmad M. Azab ${ }^{1}$, Alaa M. El-Far ${ }^{2}$ and Ayman M. El-Sayed ${ }^{1}$ \\ 1- Marine Biology and Ichthyology, Zool. Dept., Fac. Sci., Al-Azhar Univ., \\ Cairo, Egypt. \\ 2- Fisheries Division, National Institute of Oceanography and Fisheries, Egypt.
}

\section{ARTICLE INFO}

Article History:

Received: June 2, 2019

Accepted: June 15, 2019

Online: June 20, 2019

\section{Keywords:}

Boops boops

Mediterranean Sea

population structure

Age

Growth

\section{ABSTRACT}

The annual catch of bogue, Boops boops, in Egypt decreased from about $4000 \mathrm{MT}$ to be $2000 \mathrm{MT}$ in last 10 years. The present study provided information on the fisheries biology of $B$. boops, from Egyptian Mediterranean waters for management purpose. Monthly random samples of total 1367 specimens were collected from three landing sites front Alexandra during 2018. Results showed that, the total length of $B$. boops varied from 9.3 to $23 \mathrm{~cm}$, while the total weight ranged between 7.4 and 133.1 g. The length-weight relationship revealed that " $b$ " value $(2.96)$ is indicating a tendency towards isometric growth with statistically highly significant coefficient. The longevity of $B$. boops was estimated to be 4 years and age groups $\mathrm{I}^{+}$and $\mathrm{II}^{+}$were the most abundant in the catch constituting more than $85 \%$. The length at first capture and first maturity was 12.5 and $13.2 \mathrm{~cm}$ respectively. The mortalities rates were $0.671,1.589$ and $2.26 \mathrm{y}^{-1}$ for natural, fishing and total mortalities, respectively. The bogue stocks in the Mediterranean waters front Alexandria was exposed to over exploitation $(\mathrm{E}=0.70)$. For fisheries management, some measures were proposed for stock maintenance, fisheries development and catch sustainability.

\section{INTRODUCTION}

Fish products have traditionally been among the most important commodities traded in the Mediterranean Sea basin, and fish consumption has always been an integral part of people's diet. However, with the rapidly increasing demand for seafood in recent decades, marine living resources have become more vulnerable because of human fishing activities (FAO, 2018). In Egypt, fish production is rapidly increasing because of growing the aquaculture production (1008 thousand MT) which recently contributed by more than $80 \%$ of total fish production (1706 thousand MT). On the other hand, capture fisheries from natural resources undergoes gradually decreasing in last 20 years (GAFRD, 2018). The Mediterranean Sea constitutes a very important sector in the Egyptian fisheries, both for significant total catch and a large number of economically important species (UNEP, 1989). The fish production from the Alexandria coastal area (13500 MT) contributed with about $25 \%$ of 54000 MT fish landed from Mediterranean water in Egypt (GAFRD, 2018). 
Bogue, Boops boops, (Fig. 1) was the dominant fish species recorded from the Mediterranean Sea where it contributed with about $16 \%$ of fish landed in Alexandria area.

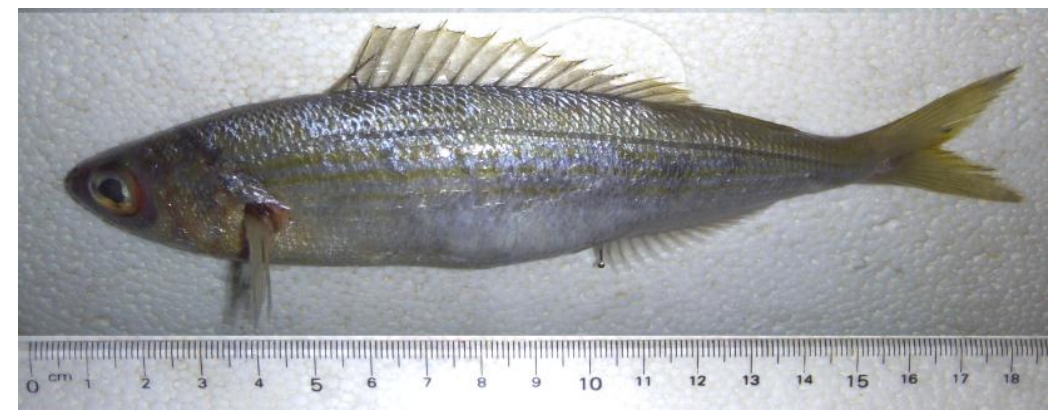

Fig. 1: Bogue, Boops boops (Linnaeus, 1758), From Mediterranean water front the coastal area off Alexandria, Egypt.

For last 10 years, B. boops catch decreased from 3677 MT in 2007 to be 2150 MT in 2016. B. boops (Lenneous,1785), is a teleost belonging to family Sparidae, inhabits the eastern Atlantic, from Norway to Angola (Bauchot \& Hureau, 1986) and the Mediterranean Sea, including the Black Sea (FishBase, 2018). Some studies had been conducted on Bogue biology in the Mediterranean waters; in Turkey (Kara \& Bayhan, 2008 \& 2015; Soykan et al, 2015), in Greece (Stergio \& Moutopoulos, 2001), in Adriatic (Hernandez, 1989), in Tunisia (Anato \& Ktari, 1986) and in Algeria (Boutiba, 1992; Ramdane et al., 2013; Rachid et al., 2014; Kherraz et al., 2016). Little biological studies were published in the Egyptian waters (Hassan, 1990; Allam, 2003; El-Okda, 2008; Mehanna, 2014).

The present study aimed to provide the required biological data of Bogue in the coastal area off Alexandria for its fisheries management purposes, development and sustainability.

\section{MATERIALS AND METHODS}

\section{Area of study:}

Fish samples were collected from three land sites (Al-Max, Al-Anfoushi and Abu Qir) in the Mediterranean Sea front Alexandria; 31 $14.1^{\prime} \mathrm{N} \& 29^{\circ} 56.6^{\prime} \mathrm{E}$ (Fig. 2).

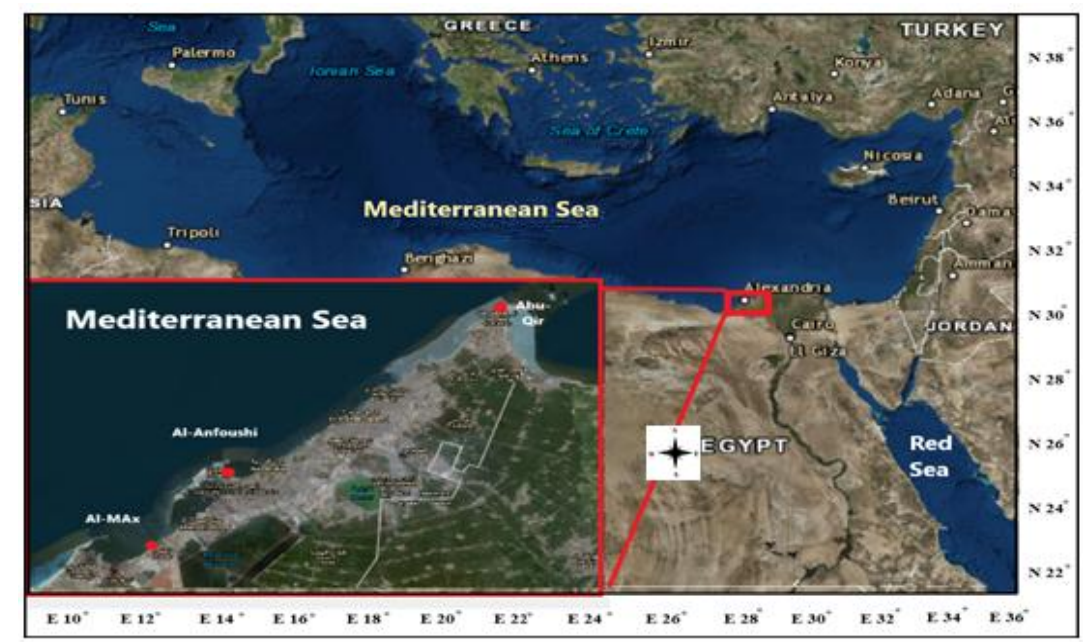

Fig. 2: Map of Egypt showing the Mediterranean coastal area off Alexandria with different landing sites during the present study. 


\section{Samples and data collection:}

Monthly samples of bogue, B. boops, were collected from different landing sites in Alexandria area during the period from January, 2018 to December, 2018. Fish samples were freshly transferred to the laboratory in ice-box for latter measuring and examination. All specimens were measured for total and standard length $(0.1 \mathrm{~cm})$ and for total and gutted weight $(0.1 \mathrm{~g})$. Scales and otolith were preserved and the samples were dissected for determination of the sex and gonad maturation.

\section{Data analysis:}

Length-weight relationship of $B$. boops was estimated by using the power equation of logarithmic modification equation: $\mathrm{W}=\mathrm{a} \mathrm{L}^{\mathrm{b}}$ (Ricker, 1975). The condition factor $(\mathrm{K})$ was monthly calculated according to Hile (1936) $\mathrm{K}=100 \mathrm{~W} / \mathrm{L}^{3}$; where $\mathrm{W}$ is the total weight $(\mathrm{g})$, and $\mathrm{L}$ is the total length $(\mathrm{cm})$. Fish age was determined using scales and von Bertelanffy growth parameters were estimated. Gonado-somatic Index (GSI) was calculated using the equation, GSI $=100 \mathrm{~W}_{\mathrm{g}} / \mathrm{W}$, where $\mathrm{W}_{\mathrm{g}}$ is gonad weight and $\mathrm{W}$ is body weight. Length-converted catch curve used to determine the total mortality (Pauly, 1984). Nature mortality (M) was estimated based on Pauly's empirical equations using the growth parameters ( $\mathrm{L}_{\infty}$ and $\mathrm{K}$ ) and water temperature $(\mathrm{T}): \ln (\mathrm{M})=-0.0152-0.279 \ln \left(\mathrm{L}_{\infty}\right)+0.6543 \ln (\mathrm{K})+0.463 \ln (\mathrm{T})$. Fishing mortality $(\mathrm{F})$ was calculated by simple subtraction $\mathrm{F}=\mathrm{Z}-\mathrm{M}$. Rate of exploitation (E) was calculated according to Cushing (1968): $\mathrm{E}=\mathrm{F} / \mathrm{Z}$. Virtual Population Analysis (VPA) modified from Jones \& van Zalinge (1981) was adapted to accommodate length frequencies. For prediction of the yield, relative yield, biomass and relative biomass-per-recruit based on the knife-edge selection model (Beverton \& Holt, 1966) was used. Figures, calculations and statistical operations were processed using MS office (ver. 2016), SPSS (ver. 20), GraphPad, and FISAT II softwares.

\section{RESULTS}

\section{Length-weight relationship:}

Total samples of 1367 of B. boops were collected from the Mediterranean Sea during the period from January 2018 to December 2018. Fish total length ranged from 9.3 to $23.1 \mathrm{~cm}$ with an average of $13.6 \pm 1.81 \mathrm{~cm}$. While, the total weight varied between 7.4 and $133.1 \mathrm{~g}$ with an average of $25.8 \pm 11.624 \mathrm{~g}$ (Table 1).

Table 1: Fish number, length, weight and samples statics of $B$. boops collected from the Mediterranean waters front Alexandria during 2018.

\begin{tabular}{cccccccc}
\hline & Sex & Fish No. & Minimum & Maximum & Average & SD & SE \\
\hline Total & M & 683 & 9.3 & 21.6 & 13.40 & \pm 1.819 & 0.0696 \\
length & F & 684 & 10.0 & 23.1 & 13.81 & \pm 1.779 & 0.0680 \\
(cm) & $\mathbf{C}$ & 1367 & 9.3 & 23.1 & 13.60 & \pm 1.810 & 0.0490 \\
Total & $\mathbf{M}$ & 683 & 7.7 & 116.9 & 24.40 & \pm 10.913 & 0.4176 \\
Weight & $\mathbf{F}$ & 684 & 7.4 & 133.1 & 27.12 & \pm 12.152 & 0.4646 \\
(g) & $\mathbf{C}$ & 1367 & 7.4 & 133.1 & 25.77 & \pm 11.624 & 0.3144 \\
\hline
\end{tabular}

*M: males, F: females; C: combines sexes, SD: standard deviation and SE: standard error.

The results revealed that the fish weight increased with the increasing in fish length increasing (Fig. 3). The length-weight relationship is expressed by the power equations:

$\mathrm{W}=0.010 \mathrm{~L}^{2.978}\left(\mathrm{R}^{2}=0.9185\right)$ for males,

$\mathrm{W}=0.012 \mathrm{~L}^{2.912}\left(\mathrm{R}^{2}=0.9128\right)$ for females,

$\mathrm{W}=0.011 \mathrm{~L}^{2.960}\left(\mathrm{R}^{2}=0.9167\right)$ for combined sexes. 


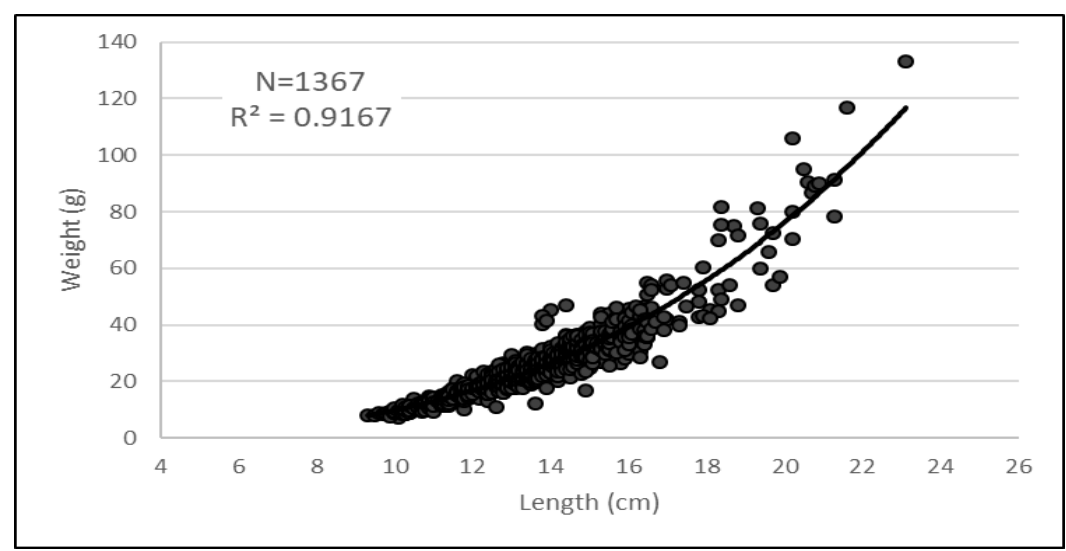

Fig. 3: Length-weight relationship of B. boops from the Mediterranean water front Alexandria during 2018.

\section{Condition factors:}

The monthly variation of condition factor $(\mathrm{K})$ mean values exhibited specific fluctuation in both sexes during different months of the years. It ranged from 0.90 to 1.09 , showing the same trend in both males and females. K mean values increased gradually from January (0.90) to June (1.06), then it gradually decreased to be 0.91 in October and rapidly increased to be 1.09 and 1.01 in November and December, respectively. In general, $\mathrm{K}$ values increased with fish size increasing. Average values of $\mathrm{K}$ increased from 0.93 in length group $9.0 \mathrm{~cm}$ to be 1.06 in length group $23.0 \mathrm{~cm}$ except groups 17.0, 18.0 and $19.0 \mathrm{~cm}$ had lower values (Figure 4).

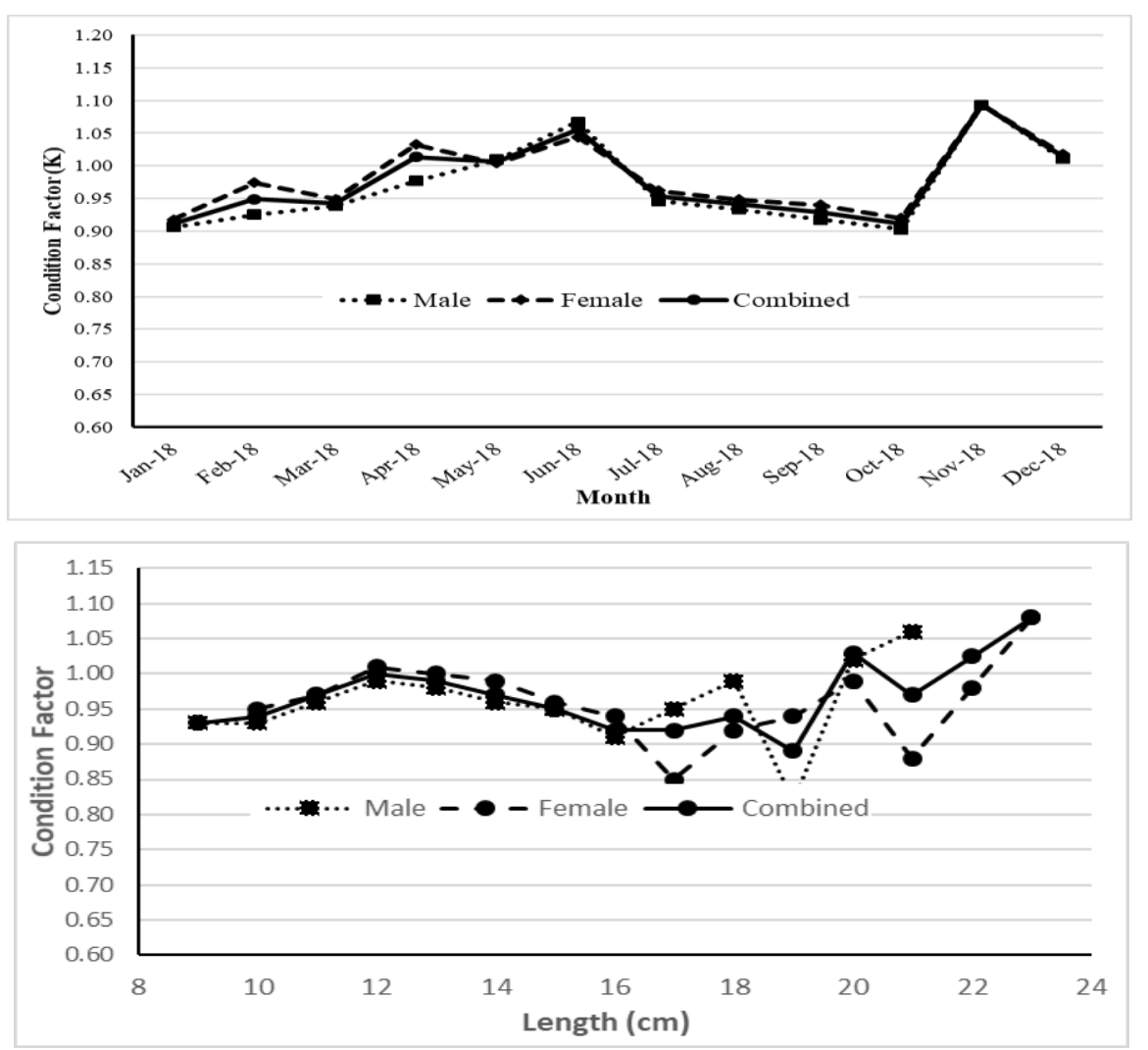

Fig. 4: Condition Factor variation of B. boops from the Mediterranean water front Alexandria during 2018 according to month (above) and according to size (lower). 


\section{Age determination:}

The longevity of $B$. boops was estimated to be 4 years by counting the annual growth rings and back calculation of 586 individual scales. Length at the end of $1^{\text {st }}$ year (I) was estimated as $8.44 \mathrm{~cm}$, at $2^{\text {nd }}$ year (II) $13.86 \mathrm{~cm}$, at $3^{\text {rd }}$ year (III) $17.91 \mathrm{~cm}$ and at $4^{\text {th }}$ year (IV) $21.03 \mathrm{~cm}$ with increment of $8.44,5.42,4.03$ and $3.12 \mathrm{~cm}$, respectively (Fig. 5).

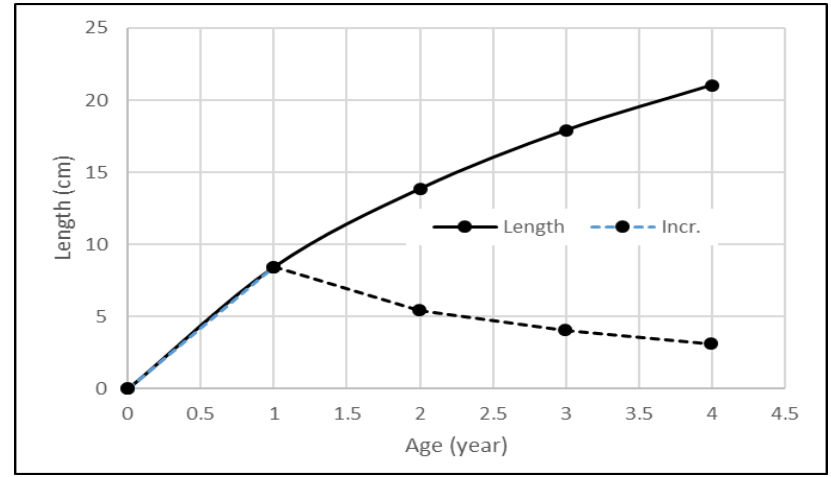

Fig. 5: Length at the end of each age group of B. boop from the Mediterranean waters fron Alexanderia during 2018.

The data of the abundance percentage revealed that, fishes belonging to age groups $\mathrm{I}^{+}$and $\mathrm{II}^{+}$were the most dominant that constituted $55.8 \%$ and $41.8 \%$ respectively followed by age group $\mathrm{III}^{+}(2.0 \%)$ while age group $\mathrm{IV}^{+}$contributed only about $0.3 \%$ (Fig. 6).

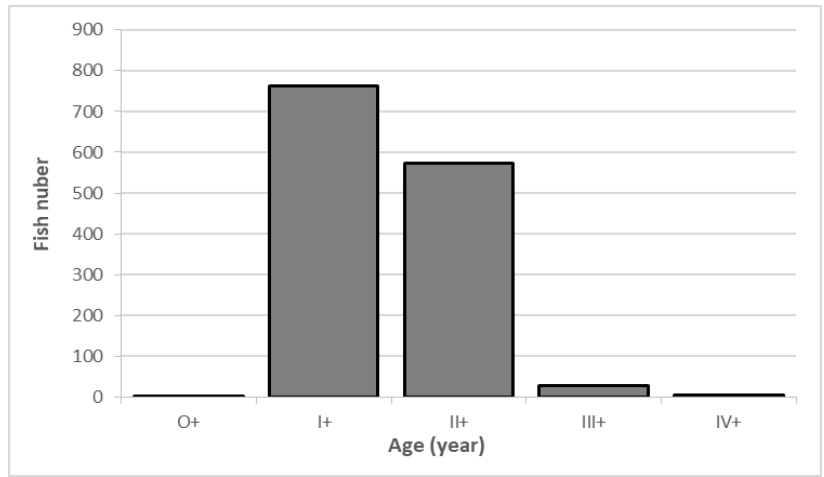

Fig. 6: Fish number corresponding to each age group of B. boops from Mediterranean water front Alexandria, Egypt during 2018.

The results revealed that the values of von Bertalanffy growth parameters were estimated as $30.65 \mathrm{~cm}, 0.279$ year $^{-1}$ and -0.156 year, for $\mathrm{L}_{\infty}, \mathrm{K}$ and $\mathrm{t}_{\mathrm{o}}$ respectively. Length-weight relationship equation was applied to calculate $\mathrm{W}_{\infty}(276.20 \mathrm{~g})$. Growth performance was calculated to be 2.418. Growth in length and in weight is represented by equations:

$$
\begin{aligned}
& \mathrm{L}_{\mathrm{t}}=30.65\left[1-\mathrm{e}^{-0.279(\mathrm{t}+0.156)}\right] \quad \text { growth in length, } \\
& \mathrm{W}_{\mathrm{t}}=276.2\left[1-\mathrm{e}^{-0.279(\mathrm{t}+0.156)}\right]^{3} \quad \text { growth in weight. }
\end{aligned}
$$

For all samples, the sex ratio was recorded to be 1: 1.03 (males to females). Monthly variation of gonado-somatic index (GSI) in both males (from 1.09\% to $1.69 \%$ ) and females (from $1.57 \%$ to $2.57 \%$ ) revealed that B. boops is spawn during the period from January to April, the peak in March. Length at first maturity estimated to be $13.2 \mathrm{~cm}$ (1.86 year) for bogue females. There is no female larger than $17 \mathrm{~cm}$ total length are immature (Fig. 7). 

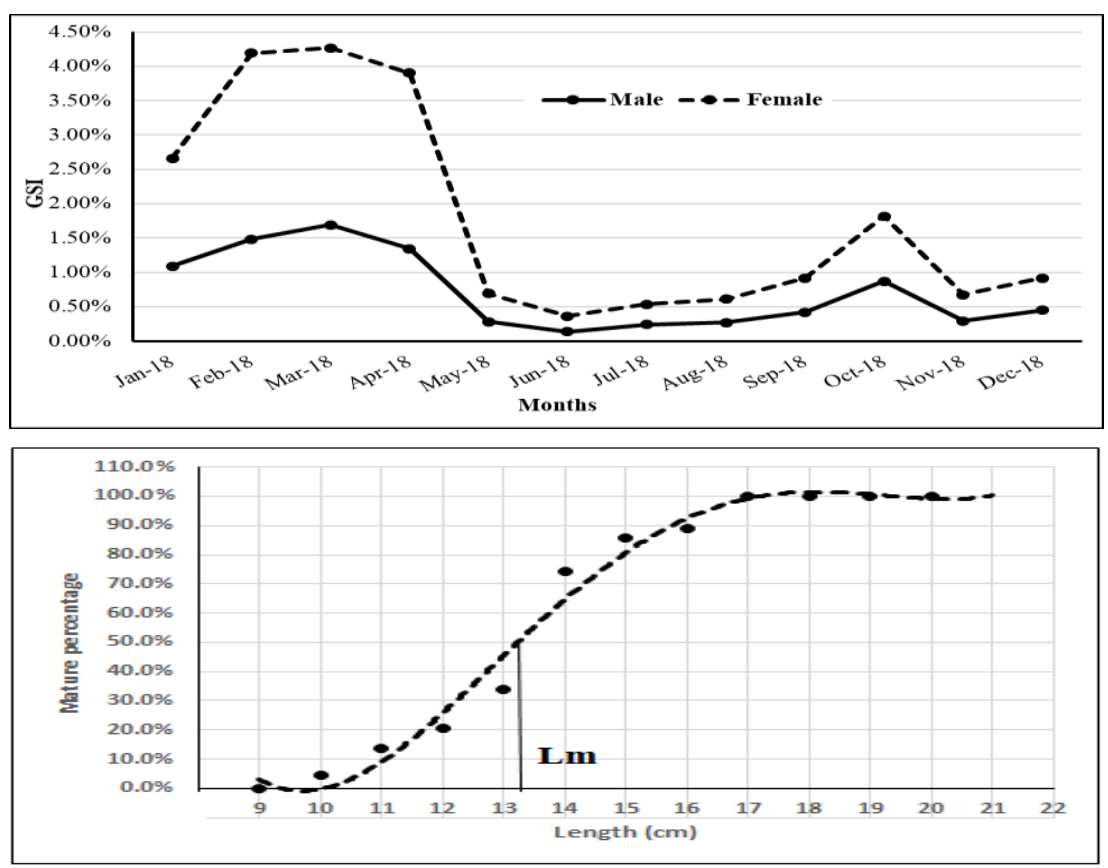

Fig. 7: Gonadosomatic index (above) and length at fist sexual maturity (lower) of $B$. boops from the Mediterranean water front Alexandria, Egypt during 2018.

\section{Population structure:}

Length at first capture $\left(\mathrm{L}_{\mathrm{c}}\right)$, length at recruit was estimated at 12.5 and $11.03 \mathrm{~cm}$ respectively. The age at first capture and at recruit were calculated to be 1.72 and 1.45 year respectively. Total mortality rate $(\mathrm{Z})$ was estimated using length converted catch curve (Fig. 8) and it was $2.26 \mathrm{y}^{-1}$ while the natural mortality (M) was calculated from Paulys' equation with water mean temperature of $20.83 \mathrm{C}^{\circ}$ and it was $0.671 \mathrm{y}^{-1}$. The fishing mortality $(\mathrm{F})$ simply calculated as Z-M $\left(1.589 \mathrm{y}^{-1}\right)$. The exploitation ratio was 0.703 . Yield per recruit (Y/R), biomass per recruit (B/R), relative Yield (Y/R') and relative biomass per recruit were estimated to be $17.90 \mathrm{~g}, 11.26 \mathrm{~g}, 0.022$ and 0.014 , respectively (Table 2).

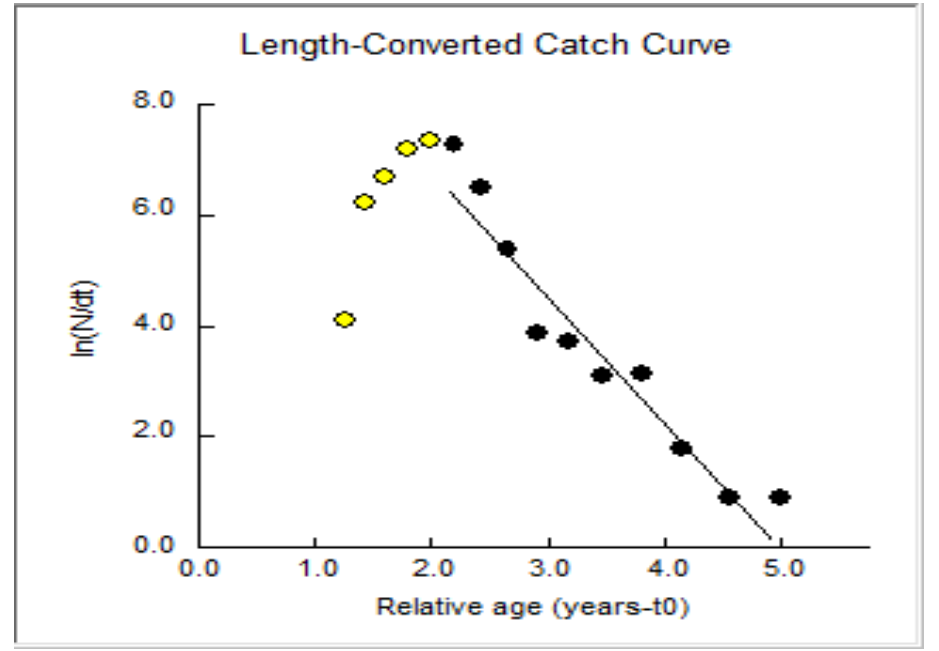

Fig. 8: Length -converted catch curve for estimation total mortality of B. boops from Mediterranean water front Alexandria, Egypt during 2018. 
Table 2: Population structure of combined sexes of B. boops from the Mediterranean waters front Alexandria during 2018.

\begin{tabular}{|c|c|c|c|c|c|}
\hline Parameter & Symbol & Value & Parameter & Symbol & Value \\
\hline Age at zero length & $\mathbf{t}_{\mathbf{0}}$ & $-0.156 y$ & Stock estimation & $\mathbf{P}$ & 3057 MT \\
\hline Asymptotic body length & $\mathbf{L}_{\infty}$ & $30.65 \mathrm{~cm}$ & Length at first maturity & $\mathbf{L}_{\mathrm{m}}(50 \%)$ & $13.2 \mathrm{~cm}$ \\
\hline Asymptotic body weight & $\mathbf{W}_{\infty}$ & $276.20 \mathrm{~g}$ & Life span & $\mathbf{t}_{\max }$ & $11.952 \mathrm{y}$ \\
\hline Coefficient of growth & $\mathbf{K}$ & $0.279 \mathrm{y}^{-1}$ & $\begin{array}{l}\text { Length at first capture at } \\
50 \%\end{array}$ & $\mathbf{L}_{\mathbf{c}}$ & $12.50 \mathrm{~cm}$ \\
\hline Total mortality & $\mathbf{Z}$ & $2.260 \mathrm{y}^{-1}$ & Age at first capture & $\mathbf{t}_{\mathbf{c}}$ & $1.73 \mathrm{y}$ \\
\hline Natural mortality & $\mathbf{M}$ & $0.671 y^{-1}$ & Length at recruitment & $\mathbf{L}_{\mathbf{r}}$ & $11.05 \mathrm{~cm}$ \\
\hline Fishing mortality & $\mathbf{F}$ & $1.589 \mathrm{y}^{-1}$ & Age at recruitment & $\mathbf{t}_{\mathbf{r}}$ & $1.45 \mathrm{y}$ \\
\hline Exploitation rate & $\mathbf{E}$ & 0.703 & Yield per recruit & $\mathbf{Y} / \mathbf{R}$ & $17.90 \mathrm{~g}$ \\
\hline Annual survival rate & $\mathbf{S}$ & $0.1044 y^{-1}$ & Biomass per recruit & $\mathbf{B} / \mathbf{R}$ & $11.26 \mathrm{~g}$ \\
\hline Annual mortality rate & $\mathbf{A}$ & $0.8957 y^{-1}$ & Relative yield per recruit & $\mathbf{Y} / \mathbf{R}^{\prime}$ & 0.022 \\
\hline Catch & $\mathbf{C}$ & $2150 \mathrm{MT}$ & Relative biomass per recruit & $\mathbf{B} / \mathbf{R}$ & 0.014 \\
\hline
\end{tabular}

Virtual Population Analysis was figured the numbers of survival, natural loss, fishing mortalities and catches corresponding to each length groups. VPA showed that fish of small sized groups were most naturally lost and the length groups from 12 to 14 were the most abundant in catch and exposed to more fishing mortalities by the fishing gears (Fig. 9).
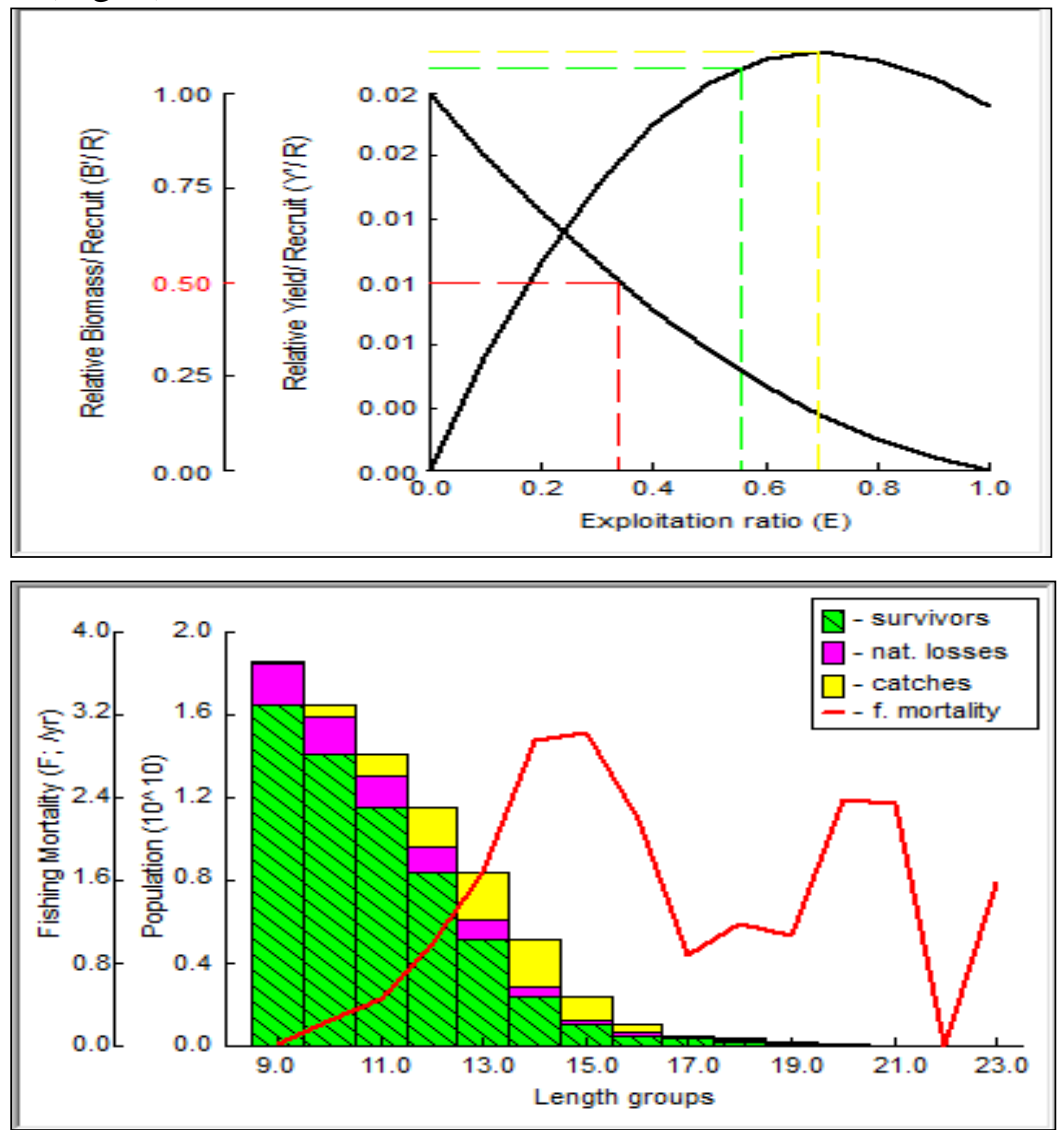

Fig. 8: Relative yield and biomass per recruit (above) and virtual population analysis (lower) of $B$. boops from Mediterranean water front Alexandria, Egypt during 2018.

\section{DISCUSSION}

The relation between length and weight is one of the most biological characters of fishes where weight of the fish increases as a function of its length. In present study, "b" values of length-weight relationship of B. boops were of usual, ranged from 2.92 to 2.98 (Hile, 1936; Martin, 1949). These values were around the ideal, 
indicating a tendency towards isometric growth (Allen, 1938). From length-weight relationship equations, it was observed that the exponent " $b$ " in the case of males (2.98) is higher than that of females (2.91), indicating the better condition of males than females of this fish. Value of ' $b$ ' in pooled data (2.96) was nearly similar that obtained by Magnusson (1987) in Cape Verde and Anato \& Ktari (1986) in Tunisian coast. Ideal value " $b=3$ " was reported by many authors (Mosaad, 1990: Djabali et al., 1993 and Merella et al., 1997). Positive allometry growth (b>3) for B. boops was recorded in the Egyptian waters (Abdallah, 2002), in Turkish waters (Hernandez. 1989; Kara \& Bayhan, 2008 \& 2015; Soykan et al., 2015) and in Tunisian water (Hajjej et al., 2010). While negative allometry growth $(b<3)$ was recorded in the Algerian waters (Zouhir et al., 2013; Rachid et al., 2014; kherraz et al, 2016) and in Egyptian waters (El-Okda, 2008) and in Spain (Valle et al., 2003). According to Pauly \& Gayanilo (1997), b values may be ranged from 2.50 to 3.50. Variations in exponent " $b$ " values of fish at various localities may be attributed to the variations in environmental conditions and localities (Andreu-Soler et al., 2006; Olim \& Borges, 2006). The parameters are affected by a series of factors including season, habitat, gonad maturity, sex, diet, stomach fullness, health and preservation techniques (Tesch, 1971; Bagenal \& Tesch, 1978; Hossain et al., 2006).

The mean value conditions factor $(\mathrm{K})$ was about 1 , indicating to the ecological conditions at the Mediterranean Sea are nearly suitable for the growth of these fishes. These observations were differed with that obtained by Soykan et al. (2015) who recorded 0.266 at Aegean Sea, Turkey and attributed the low value of condition factor to the pollution problems in this sea. In the present study, K-factor exhibited specific fluctuation in both sexes during the different months of the years. In males and females, the highest value of K-factors (1.09) was recorded during November and the lowest value (0.90) occurred during January and October. The variation in condition factor $(\mathrm{k})$ reflects the physiological state of the fish in relation to its welfare, nutritional aspect, gonad development (Laleye, 2000), environmental conditions, stress and pollution (Angelescu et al., 1958).

Age determination is essential for fishery assessment and for the management of Bogue fisheries (Gordo 1995; Panfili et al. 2002; Sana et al. 2005). A number of 586 scales of fishes ranging from 9.0 to $23.1 \mathrm{~cm}$ total length were observed and used for estimation of the growth parameters. The results revealed that the maximum life span of $B$. boops was 4 years, and age group $\mathrm{I}^{+}$and $\mathrm{II}^{+}$were the most frequent in the catch, constituting together more than $90 \%$. On the other hand, the age group $\mathrm{III}^{+}, \mathrm{IV}^{+}$ and $0^{+}$were represented by very small percentages in the catch. Growth parameters of B. boops were reported in different locations. $\mathrm{L}_{\infty}$ ranged from 24.0 to $36.0 \mathrm{~cm} ; \mathrm{k}$ ranged from 0.17 to $0.54 ; \mathrm{t}_{\mathrm{o}}$ ranged from -1.94 to -0.33 year and performance ranged from 2.15 to 2.60 . In the present study, the growth parameters were laying in the ranges that recorded in previous studies in the Mediterranean waters except value of $t_{o}$ (Table 3). The difference in growth parameters between different locations could be attributed to the difference in fish size, fishing pressure and/or due to the difference in ecological parameters.

In the present study, the monthly distribution of gonado-somatic index values indicated that its values were peaked from January to April (i.e. during the spawning season). These results agreed mostly with other studies (Mouneimne, 1978 in Libanon waters; Anato \& Ktari, 1983 in Tunisian coasts; Hassan, 1990 in Egyptian waters and Massaro, 2012 in Canary Island). Minor differences in the spawning season may reflect different temperature regimes and/or feeding dominance among the areas (Kashiwagi et al., 1987). 
Table 3: Growth parameters $\left(\mathrm{L}_{\infty}, \mathrm{K}\right.$ and $\mathrm{t}_{\mathrm{o}}$ ) and the growth performance of Boops boops from different

\begin{tabular}{|c|c|c|c|c|c|c|}
\hline Location & Sex & $\mathbf{L}_{\infty}(\mathbf{c m})$ & $\mathbf{K}$ & $\mathbf{t}_{\mathrm{o}}($ year $)$ & $\varnothing$ & Reference \\
\hline Adriatic Sea & $\mathbf{C}$ & 33.89 & 0.17 & -1.3 & 2.28 & Hernandez, 1989 \\
\hline Algeria & $\mathbf{F}$ & 27.30 & 0.22 & -1.94 & 2.21 & \\
\hline Algeria & M & 26.60 & 0.21 & -2.6 & 2.17 & Djabali et al., 1990 \\
\hline Algeria & $\mathbf{F}$ & 34.13 & 0.26 & -1.50 & 2.48 & \\
\hline Algeria & $\mathbf{M}$ & 26.78 & 0.38 & -0.75 & 2.43 & Kherraz et al., 2016 \\
\hline Algeria & $\mathbf{F}$ & 30.66 & 0.30 & 0.00 & $2.45^{*}$ & \\
\hline Algeria & M & 26.66 & 0.30 & 0.00 & $2.33^{*}$ & Bouazız et al., 2010 \\
\hline Cyprus & C & 24.00 & 0.53 & -0.45 & $2.49^{*}$ & Livadas, 1989 \\
\hline Egypt & $\mathbf{C}$ & 29.80 & 0.18 & -1.33 & 2.20 & Hassan, 1990 \\
\hline Egypt & $\mathbf{C}$ & 31.68 & 0.153 & -1.78 & 2.19 & Allam, 2003 \\
\hline Egypt & $\mathbf{F}$ & 29.70 & 0.25 & -0.70 & 2.34 & \\
\hline Egypt & M & 28.10 & 0.18 & -1.13 & 2.15 & El-Haweet et al., 2005 \\
\hline Egypt & $\mathrm{C}$ & 30.11 & 0.15 & -1.51 & 2.14 & El-Okda, 2008 \\
\hline Egypt & $\mathbf{C}$ & 27.24 & 0.54 & -0.33 & 2.60 & Mehanna, 2014 \\
\hline Greece & $\mathbf{C}$ & 36.00 & 0.40 & --- & 2.71 & Tsangridis \& Filippousis, 1991 \\
\hline Morocco & C & 31.50 & 0.28 & -0.96 & $2.44^{*}$ & Zoubi, 2001 \\
\hline Portugal & $\mathbf{C}$ & 28.06 & 0.22 & -1.42 & $2.24^{*}$ & Monteiro et al., 2006 \\
\hline Tunisia & $\mathbf{C}$ & 32.27 & 0.111 & -1.69 & 2.07 & Anato \& Ktari, 1986 \\
\hline Turkey & $\mathbf{F}$ & 30.79 & 0.239 & -0.90 & 2.36 & \\
\hline Turkey & M & 29.87 & 0.243 & -0.98 & 2.33 & Kara \& bayhan, 2015 \\
\hline Turkey & $\mathbf{C}$ & 29.58 & 0.266 & -1.14 & 2.37 & Soykan et al., 2015 \\
\hline Egypt & C & 30.65 & 0.279 & -0.16 & 2.42 & Present study \\
\hline
\end{tabular}

$\mathrm{C}$, combined sexes; F, females; $\mathrm{M}$, males and * the value of $\varnothing$ was calculated

Length at first maturity in the present study for females $(13.2 \mathrm{~cm})$ was agreed with that observed in Gulf of Lion (Girardin \& Quignard, 1986), in Libanon waters (Mouneimne, 1978), in Adriatic Sea (Hernández, 1989) and in Egyptian waters (ElAgmy et al., 2004). It was smaller than that observed by Monteiro et al. (2006) in Portugal and Massaro (2012) in Canary Island.

The obtained value of $\mathrm{L}_{\mathrm{r}}$ for $B$. boops was $11.05 \mathrm{~cm}$, while the value of $\mathrm{L}_{\mathrm{c}}$ was $12.2 \mathrm{~cm}$, whereas the value of females $\mathrm{L}_{\mathrm{m}}$ was $13.2 \mathrm{~cm}$. Results revealed that the estimated value of $\mathrm{L}_{c}$ was lower than estimated $\mathrm{L}_{m}$, which was an evidence of overfishing that prevent them from spawning at least once before being caught. Estimated exploitation ratio (E) was 0.703/year, which seemed to be higher than 0.5; optimum level of exploitation (Gulland, 1971), indicating that the stock of B. boops is overexploited. Yield per Recruit (Y/R) analysis shows a clear status of growth overexploitation, due both to a high fishing mortality and an exploitation of the fishery based on juveniles under the minimum legal size. Also, the stock is in danger of recruitment overexploitation due to the decreasing trend in recruitment.

For management purpose, length of first capture should be larger than $13.2 \mathrm{~cm}$, decrease fishing effort of trawls during winter season (bogue spawning period) and the current exploitation rate should be reduced from 0.70 to be $<0.50$ i.e. the fishing mortality should be reduced by $58.0 \%$ of current fishing mortality to maintain a sufficient spawning biomass for sustainability.

\section{REFERENCES}

Abdallah, M. (2002). Length-weight relationship of fishes caught by trawl off Alexandria, Egypt. Naga, ICLARM Q., 25: 19-20.

Allam, M. S. (2003). Growth, mortality and yield per recruit of bogue, Boops boops (L.), from the Egyptian Mediterranean waters off Alexandria. Medit. Mar. Sci., 4: 87-96. 
Allen, K. R. (1938). Some observations on the biology of the trout (Salmo truta) in Windermere. J. Anim. Ecol., 7: 333- 349.

Anato, C. B. and Ktari, M. H. (1983). Reproduction of Boops boops (Linne, 1758) and of Sparpa salpa (Linne, 1758), fish teleosteens, sparidae of the Tunis. Bull Inst Natl Sci Tech Oceanogr Peche Salammbo, 10:49-53.

Anato, C. B. and Ktari, M. H. (1986). Age and growth of Boops boops (Linne, 1758) sparidae teleostean fish of the Tunisian coast. Bull Inst Natl Sci Tech Oceanogr Peche Salammbo, 13:33-54.

Andreu-Soler, A.; Oliva-Paterna, F. J. and Torralva, M. (2006). A review of lengthweight relationships of fish from the Segura River basin (SE Iberian Peninsula). J. Appl. Ichthyol., 22: 295-296

Angelescu, V.; Gneri, F. and Nani, A. (1958). La Del Mar Argentine Hake (biology and taxonomy). Hydro gels. Nav. Public., H1004: 1- 224.

Bauchot, M. L. and Hureau, J. C. (1986). Sparidae. p. 883-907. In Whitehead, P.J.P.; Bauchot, M.-L.; Hureau, J.-C; Nielsen, J. and Tortonese, E. (eds.) Fishes of the North-Eastern Atlantic and the Mediterranean. Vol. 2. UNESCO, Paris.

Beverton, R. J. and Holt, S. J. (1966). Manual of methods for fish stock assessment: Part II. Tables of yield function. FAO Fisheries Technical Paper, 38: 1- 67 pp.

Bouaziz, A.; Djebbour, O. and Benina, R. (2010). Estimation de la biomasse exploitable et du point de référence biologique, F0.1, de la bogue de la région d'Alger. Congrès International Gestion systémique des ressources halieutiques, GSRH-29-30 novembre 2010. ENSSMAL. Alger, p: 1.

Boutiba, Z. (1992). Les mammifères marins d'Algérie. Statut, Répartition, Biologie et Ecologie. Thèse Doct. Etat: 575pp.

Cushing, D. H. (1968). Fisheries biology. A study of population dynamic. Univ. Wisconsin press, Madison., $200 \mathrm{p}$.

Djabali, F.; Boudraa, S.; Bouhdid, A.; Bousbia, H.; Bouchelaghem, E. H.; Brahmi, B.; Dob, M.; Derdiche, O.; Djekrir, F.; Kadri, L.; Mammasse, M.; Stambouli, A. and Tehami, B. (1990). Travaux re'alise's sur les stocks pe'lagiques et de'mersaux de la re'gion de Be'ni-saf. FAO Fish. Rep., 447:160-165

Djabali, F.; Mehailia, A.; Koudil, M. and Brahmi, B. (1993). Empirical equations for the estimation of natural mortality in Mediterranean teleosts. Naga ICLARM Q., 6: 35-37.

El-Agamy, A.; Zaki, M. I.; Awad, G. S. and Negm, R. K. (2004). Reproductive biology of Boops boops (family Sparidae) in the Mediterranean environment. Egyptian Journal of Aquatic Research, 30(B): 241-254.

El-Haweet, A.; Hegazy, M.; Abu-Hatab, H. and Sabry E. (2005). Validation of length frequency analysis for Boops boops (Bogue) growth estimation. Egypt J. Aquat. Res., 31(1):399-408

El-Okda, N. L. (2008). Age and growth of Boops boops (L.) from Egyptian Mediterranean waters off Alexandria Egypt. J. Aquat. Biol. Fish., 12 (1):13 -23.

FAO, Food and Agriculture Organization, (2018). The State of World Fisheries and Aquaculture 2018 - Meeting the sustainable development goals. Rome. License: CC BY-NC-SA 3.0 IGO.

FishBase, (2018). Froese, R. and Pauly, D. Editors. World Wide Web electronic publication. www.fishbase.org, version, 2018.

GAFRD, General Authority for Fish Resources Development (2018). Book Year of Fishery Statistic. Egyptian Ministry of Aquaculture, Cairo.

Girardin, M. and Quignard, J. P. (1986). Growth of the Boops boops Linne, 1758 (Sparidae) in the Gulf of Lion. J Appl Ichthyol, 2: 22-32 
Gordo, L. S. (1996). On the age and growth of bogue, Boops boops (L.), from the Portuguese coast.Fisheries Management and Ecology, 3(2): 157-164.

Gulland, J. A. (1971). The fish resources of the Ocean, Fishing News Books, Ltd., West Byfleet, UK, 255 pp.

Hajjej, Gh.; Abdallah, H.; Hassan, A.; Mourad, Ch.; Abderrahmen, B. and Othman, J. (2010). Length-weight relationships for 13 fish species from the Gulf of Gabes (Southern Tunisia, Central Mediterranean). African Journal of Biotechnology, 9(37): 6177-6181, 13 September, 2010 ISSN 1684-5315

Hassan, M. W. A. (1990). Comparative biological studies between two species of family Sparidae, Boops boops and Boops salpa in Egyptian Mediterranean waters. M. Sc. thesis, Faculty of Science, Alexandria University, $198 \mathrm{p}$

Hernandez, A. V. (1989). Study on the age and growth of bogue (Boops boops L.) from the central Adriatic Sea. Cybium., 13: 281-288.

Hile, R. (1936). Age and growth of the ciscoe, Leveichthys artedi (Lesueur), in the lakes of the Northern high lands, Wisconsin. Bull. Mar. Fish, U.S., 48 (19): 211 $-317$.

Hossain, M. Y.; Ahmed, Z. F.; Leunda, P. M.; Roksanul, A. K.; Jasmine, S.; Oscoz, J.; Miranda, R. and Ohtomi, J. (2006). Length-weight and length-length relationships of some small indigenous fish species from the Mathabhanga River, southwestern Bangladesh. J. Appl. Ichth., 22: 301-303.

Jones, R. and van Zalinge, N. (1981). Estimations of mortality rate and population size for shrimp in Kuwait waters. Kuwait Bull. Mar. Sci., 2: 273-288.

Kara, A. and Bayhan, B. (2008). Length-weight and length-length relationships of the bogue, Boops boops (Linneaus, 1758) in Izmir Bay (Aegean Sea of Turkey). Belg. J. Zool., 138(2): 154-157.

Kara, A. and Bayhan, B. (2015). Age and growth of Boops boops (Linnaeus, 1758) in Izmir Bay, Aegean Sea, Turkey J. Appl. Ichthyol., 31: 620-626

Kashiwagi, M.; Sakaki, H.; Taka hashi, T. and Iwai, T. (1987). A relationship between egg size and hatching rate in Japanese whiting Sillago joponica. Nippon Suisan Gakkaishi, 53(12): 2105-2110.

Kherraz, A.; Kherraz, A.; and Boutiba, Z. (2016). Interrelationship age and growth of Boops boops (Linnaeus, 1758) in Western Mediterranean coasts of Algeria. Advances in Environmental Biology, 10(4): 140- 145.

Laleye, P. A. (2000). Length-weight and length-length relationships of fishes from the Oueme River in Benin (West Africa). J. Appl. Ichthiol, 22: 330 - 333.

Linnaeus, C. (1758). Systema Naturae (Ed. 10), (Systema naturae per regna tria naturae, secundum classes, ordines, genera, species, cum characteribus, differentiis, synonymis, locis. Tomus I. Editio decima, reformata.) Holmiae. vol. 1. 824 pp. Nantes and Pisces in Tom., 1: 230-338.

Livadas, R. (1989). The growth and maturity of bogue (Boops boops). Family Sparidae, in the water of Cyprus. In: Savini, M. and Caddy, J. F. (ed) Report of the second technical consultation of general fisheries council for the Mediterranean on Stock Assessment in the Eastern Mediterranean. (1988) Greece. FAO Fisheries Report no., 412:52-57

Magnusson, J. (1987). ICEIDA/Cape Verde Islands Fisheries Project. Survey of demersal fish resources in the waters off Cape Verde Islands. IV. Report: summary of information on species. Icelandic International Development Agency/Marine Research Institute 114 pp. 
Martin, W. R. (1949). The mechanics of environmental control of body form in fishes. University of Toronto Studies in Biological series 58, Ontario Fisheries Research Laboratory, 70: 1-72.

Massaro, A. (2012). Reproductive Biology of Boops Boops (Linnaeus, 1758) Off Gran Canaria (Canary Islands): A Preliminary Study", Ph.D. in Sustainable Management of Fisheries Resources.

Mehanna, S. (2014). Stock Assessment of Bogue, Boops Boops (Linnaeus, 1758) from the Egyptian Mediterranean Waters. In: Behnassi M. (eds.) 2014. Vulnerability of Agriculture, Water and Fisheries to Climate Change: Toward Sustainable Adaptation Strategies, DOI10.1007/978-94-017-8962-2_20, Springer Science+Business Media Dordrecht.

Merella, P.; Quetaglas, A.; Alemany, F. and Carbonella, A. (1997). Length-weight relationship of fishes and cephalopods from the Balearic Islands (western Mediterranean). Naga. ICLARM Quaterly, 20 (3- 4): 66-68.

Monteiro, P.; Bentes, L.; Coelho, R.; Correia, C.; Goncalves, J. M.; Lino, P. G.; Ribeiro, J. and Erzini, K. (2006). Age and growth, mortality, reproduction and relative yield per recruit of the bogue, Boops boops Linn., 1758 (Sparidae), from the Algarve (south of Portugal) longline fishery. J Appl Ichthyol, 22(5):345-352

Mosaad, M. N. (1990). Biological studies on five fish species from The Mediterranean Sea, Egypt. I-Length-weight relationship and condition factors. Proc. Zool. Soc. A. R. E., 21: 331-344.

Mouneimne, N. (1978). Poissons des cotes du Liban. These Universitè Pierre et Marie Curie, Paris VI, 490 pp.

Olim, S. \& and Borges, T. C. (2006). Weight-length Relationships for eight species of the family Triglidae discarded on the South coast of Portugal. J. Appl. Ichthyol, 22: 257-259.

Panfili, J.; de Pontual, H.; Troadec, J. P. and Wright, P. J. (eds) (2002). Manual of fish Sclerochronology. IFREMER-IRD Co-edition, Brest. $464 \mathrm{p}$.

Pauly, D. and Gayanilo, Jr. F. (1997). A Bee: An alternative approach to estimating the parameters of a length-weight relationship from length frequency samples and their bulk weights. NAGA ICLARM, Manila, Philippines.

Pauly, D. (1984). Length-converted catch curves. A powerful tool for fisheries research in the tropics. (Part II). ICLARM Fishbyte 2(1):17-19.

Rachid, B.; Salim M. and Zitouni B. (2014). Estimation of the exploitable biomass and the reference biological point, F0.1, of bogue, Boops boops L., in the bay of Bou-Ismail, centre Algerian. Journal of Biodiversity and Environmental Sciences (JBES), 5(2): 420-427, 2, ISSN: 2220- 6663.DOI: 10.1.1.651.275.

Ramdane, Z.; Trilles, J-P.; Mahé, K. and Amara, R. (2013). Metazoan ectoparasites of two teleost fish, Boops boops (L.) and Mullus barbatus barbatus (L.) from Algerian coast: diversity, parasitological index and impact of parasitism. Cybium, 37(1-2): 59-66.

Ricker, W. E. (1975): Computation and interpretation of biological statistics of fish population. Bull. Fish. Res. Bd. Canada. (191), 328 pp.

Sana, K.; Gaamour, A.; Zylberberg, L.; Meunier, F. and Romdhane, S. (2005). Age and growth of bogue, Boops boops, in Tunisian waters. Acta Adriat, 46(2):159175

Soykan, O.; İlkyaz, A. T.; Metin, G. and Kinacigil, H. T. (2015). Growth and reproduction of Boops boops, Dentex macrophthalamus, Diplodus vulgaris, and 
Pagellus acarne (Actinopterygii: Perciformes: Sparidae) from East-Central Aegean Sea, Turkey. Acta Ichthyol. Piscat., 45: 39-55.

Stergiou, K. I. and Moutopoulos, D. K., (2001). A review of length-weight relationships of fishes from Greek marine waters. Naga, ICLARM Q., 24: 2339.

Tesch, W. (1971). Age and growth. In: RICKER, W.E. (ed), Methods for Assessment of Fish Production in Fresh Waters, $2^{\text {nd }}$ ed. International Biological Programme, Oxford and Edinburgh, 97- 130.

Tsangridis, A. and Filippousis, N. (1991). Use of length-frequency data in the estimation of growth parameters of three Mediterranean fish species: bogue (Boops boops L.), picarel (Spicara smaris L.) and horse mackerel (Trachurus trachurus L.). Fish Res 12:283-297

UNEP, (1989). Directory of marine and coastal protected areas in the Mediterranean region (Part I: Sites of biological and ecological value. MAP Technical Reports Series No.26. Athens.

Valle, C.; Bayle, J. T. and Ramos, A. A. (2003). Weight-length relationships for selected fish species of the western Mediterranean Sea. J. oAppl. Ichth., 19: 261-262.

Zoubi, A. (2001). Etude de la biologie de croissance des principaux stocks demersaux de la mediterranee marocaine. Rapp Comm Int Mer Médit 36:341.

\section{ARABIC SUMMARY}

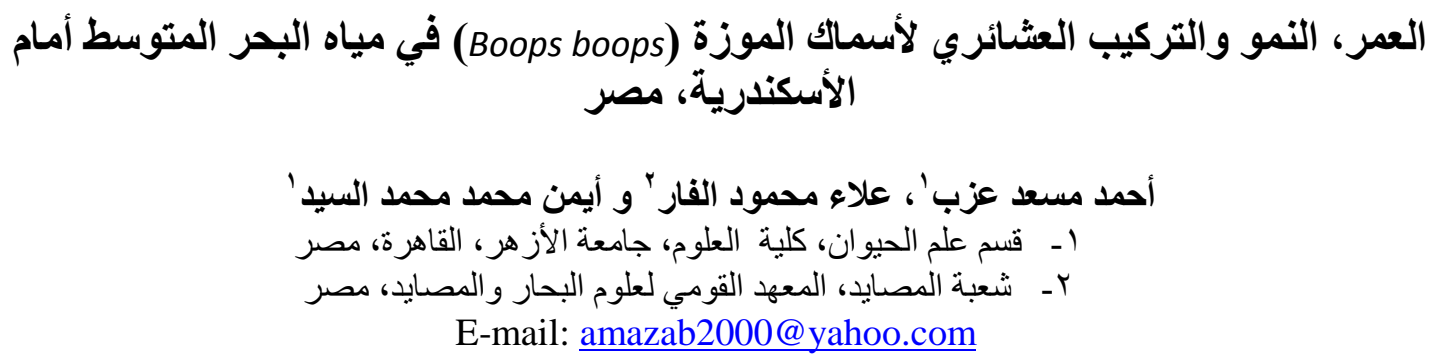

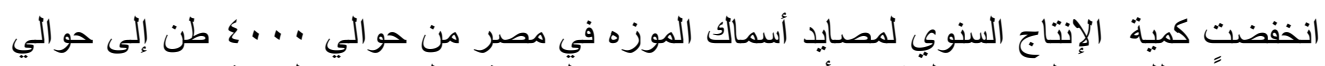

النو ل . . .

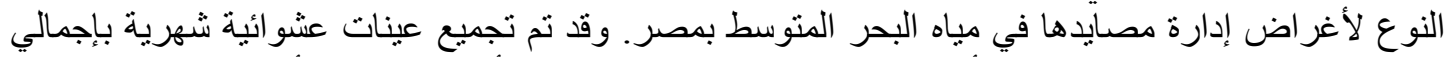

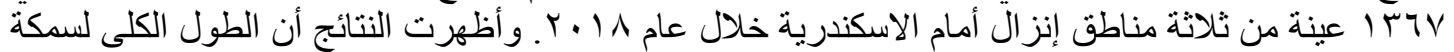

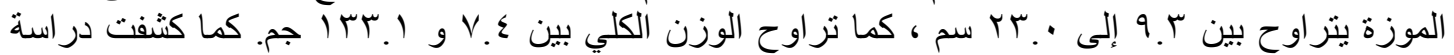

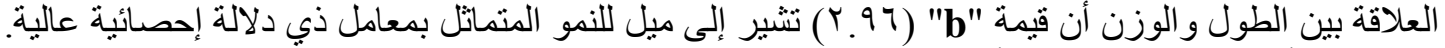

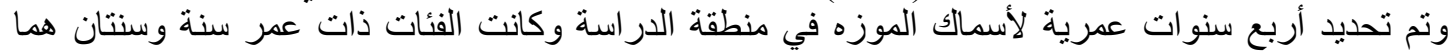

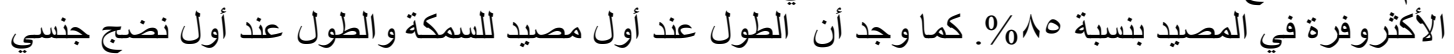

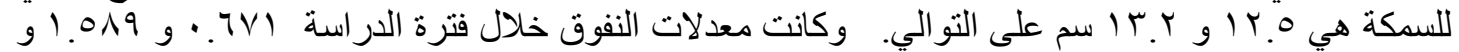

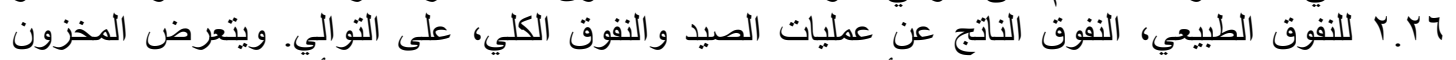

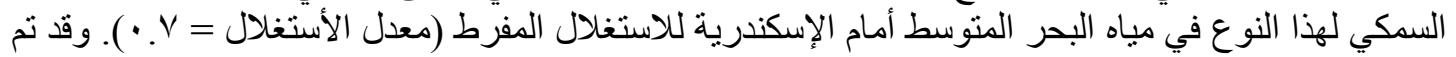

اقتر اح بعض التدابير الخاصة بإدارة مصايد هذا النو علصيانة لصنية مخزونتها وتنمية واستدامة مصايدها. 